J. Product. \& Dev., 12(1): 45 - 60 (2007)

\title{
INFLUENCE OF GLYCINEBETAINE AND NITROGEN LEVELS ON GROWTH AND YIELD OF BARLEY (HORDEUM VULGARE L.) UNDER DROUGHT CONDITIONS
}

\author{
M. Abd Alla Kotb * and A. B. Gaballah ** \\ *Department of Agronomy, Faculty of Agriculture, Suez Canal University, Ismailia, \\ Egypt. \\ ** Plant Production Department (Agronomy), Institute of Efficient Productivity, \\ Zagazig University, Egypt.
}

\section{ABSTRACT}

Two field experiments were conducted in a sandy soil in the extension field in El-Salhia region, Sharkia Governorate during 2004/2005 and 2005/2006 seasons to study the effect of three levels of nitrogen (45, 65 and 85 $\mathrm{kg} \mathrm{N} / \mathrm{fad})$ and three glycinebetaine rates $(0,8$ and $12 \mathrm{mM} / \mathrm{fad})$ on the growth and yield of barley (Giza $124 \mathrm{cv}$.) under two irrigation intervals (weekly irrigated and di-weekly irrigated). The most important findings could be summarized as follows:

Irrigation every two weeks instead of one week reduced significantly all growth attributes. The relative decrease percentages were 25.41 and $22.93 \%$, 22.63 and $19.98 \%$, and 25.11 and $26.19 \%$ for flag leaf blade area, total chlorophyll and relative water content in both seasons, respectively.

Addition of $85 \mathrm{~kg} \mathrm{~N} /$ fad increased these traits by 12.80 and $13.63 \%, 1.88$ and $3.50 \%$, and 3.28 and $4.59 \%$ in the first and second seasons, respectively compared with the addition of $45 \mathrm{~kg}$ N/fad. Meanwhile, using $12 \mathrm{mM}$ glycinebetaine $(G B)$ increased these traits by 20.63 and 23.06\%, 32.30 and $35.80 \%$, and 22.57 and $30.40 \%$ in the first and second seasons, respectively compared with untreated plants. Under stress or non stress condition, increasing $N$ level from 45 to $85 \mathrm{~kg} /$ fad without $G B$ did not increase total chlorophyll. Meanwhile, this trait was increased significantly with increasing GB from zero to $12 \mathrm{mM}$.

Prolonging the period of irrigation from 7 to 14 day reduced significantly the yield and its attributes. The relative reduction percentages for grain and straw yields were 22.73 and $26.02 \%$ and 26.73 and $24.79 \%$ in both seasons, respectively.

Increasing $\mathrm{N}$-level from $45 \mathrm{~kg}$ to $85 \mathrm{~kg} \mathrm{~N} /$ fad increased grain yield, straw yield and mean productivity by 12.84 and $12.78 \%, 16.43$ and $14.7 \%$, and 12.88 and $12.85 \%$ in both seasons, respectively. Meanwhile, the relative increase percentages due to application of $12 \mathrm{mM} \mathrm{GB/fad} \mathrm{compared} \mathrm{with} \mathrm{zero}$ GB were 21.27 and $24.77 \%, 24.82$ and $26.83 \%$, and 21.30 and $24.73 \%$ for these traits in both seasons, respectively.

The interaction between frequent irrigation, zero $G B$ and $45 \mathrm{~kg} \mathrm{~N} / f a d$ gave 11.38 ardab/fad compared with 15.34 ardab/fad which was obtained 
from frequent irrigation, $8 \mathrm{mM} \mathrm{GB/fad}$ and $85 \mathrm{~kg} \mathrm{~N} / \mathrm{fad}$. Meanwhile, the interaction between drought condition, zero $G B$ and $45 \mathrm{~kg} N / f a d$ gave 8.66 ardab/fad compared with 11.69 ardab/fad which was obtained from drought condition, $8 \mathrm{mM} \mathrm{GB} / \mathrm{fad}$ and $85 \mathrm{~kg} \mathrm{~N} /$ fad treatments.

Key words: barley, glycinebetaine, $\mathrm{N}$, drought, growth and yield.

\section{INTRODUCTION}

Barley is one of the most important winter crops in the North West Coast and North Sinai. It is cultivated under rainfed conditions and under sprinkler irrigation system in the new reclaimed lands. It is used for feeding animals and also as a food by Arabian tribes who live in the desert and in dry regions. In addition, barley is the backbone of malting in brewing industry. Most of barley grown in sandy soil, is suffering from adverse conditions such as lake of water and poor soil fertility levels.

An increase in number of irrigations up to 4 enhanced barley growth as expressed in total number of tillers and dry matter accumulation at 40 and 80 days after sowing and at harvest. Significant improvement in effective tillers, grain number and weight per ear and yield was recorded by 4 irrigations (Tanoj- Chaudhary and Sharma, 2003). Meanwhile, drought during the vegetative growth stage indirectly affects yield potential by adversely affecting leaf area (Talukder, 1987) and photosynthetic capacity $(\mathrm{Ni}, 1992)$ that is available during grain set and filling. Moreover, drought during flowering reduces yield potential directly by decreasing the total number of grains (Ehaid et al., 1988).

It was found that increasing $\mathrm{N}$-application led to increase the water consumptive use, the water use efficiency of malting barley, and soil moisture extraction (Paramjit et al., 2001). It is well known that $\mathrm{N}$ is largely used in synthesis of protein and structurally is a part of the chlorophyll molecule. Nitrogen fertilizer with marginal additional water use increased barley yield linearly by $45.15 \%$ (Sing and Kumar (1981). Basha and El-Bana (1994) and Abd Alla, Maha (2004) reported that splitting $\mathrm{N}$ rates into three equal doses significantly increased yield and its attributes of barley. Moreover, El-Moselhy and Zahran (2003) noticed that adding N fertilizer up to $60 \mathrm{~kg} \mathrm{~N} / \mathrm{fad}$ to barley produced significant increase in each of plant height, spike length, number of spikes $/ \mathrm{m}^{2}$, number and weight of grains/spike, straw yield and grain yield. In addition, El Bawab et al. (2003) showed that plant height, number of spikes $/ \mathrm{m}^{2}$, and biological and grain yields were significantly increased due to increasing the amount of irrigation water up to $942 \mathrm{~m} 3$ and $\mathrm{N}$ fertilizer rate up to 60 $\mathrm{Kg} \mathrm{N} / \mathrm{fad}$.

Accumulation of solutes, either actively or passively, is an important adaptation mechanism for plants in response to osmotic stress. The accumulation of stress metabolites like proline, sugars, amino acids and betaines to maintain structural and metabolic integrity, occurs in response to drought and other stresses. Glycinebetaine ( $\mathrm{N}, \mathrm{N}$, and $\mathrm{N}$ - trimethylglycine) is accumulated by many species of Gramineae, Amaranthaceae, Malvaceae and Poaceae families. Glycinebetaine (hereafter referred to as betaine) is a common compatible solute in many different 
organisms, including higher plants (Grote et al., 1994 and Rhodes and Hanson, 1993). For barley plants, an important response to stress conditions is the induction of synthesis of the osmoprotactant glycinebetaine (Rhodes and Hanson, 1993).

Using foliar application of glycinebetaine (GB) that protect the plant by acting as an osmolytic maintaining the water balance between the plant cell and the environment and by stabilizing macromolecules during cellular dehydration and at high salt concentration is a major goal for improving drought tolerance of barley in arid zones as in Egypt. It has been shown that GB, when applied to foliage, is translocated from leaves to other plant parts within several hours (Makela et al., 1996), where it acts as a non-toxic cytoplamic osmolyte and plays a central role in adaptation to stress (Martin et al, 1997 and Jagendrof and Takab, 2001). Allard et al., (1998) found that foliar applied GB prevented photoinhibition in wheat during drought stress. Exogenous glycinebetaine tended to increase photosynthetic activity, nitrogen fixation, leaf area and grain yield when it was applied to maize, sorghum and wheat (Agboma et al., 1997 \& Naryyar and Walia, 2004). Moreover, Abd Alla Kotb (2005) found that 8 and $12 \mathrm{mM} \mathrm{GB/fad} \mathrm{recorded} \mathrm{the} \mathrm{highest} \mathrm{values} \mathrm{of} \mathrm{growth}$ parameters, yield and its attributes of wheat.

Therefore, the present investigation aimed to investigate the effect of foliar application of glycinebetaine and $\mathrm{N}$ fertilizer level to improve drought tolerance of barley grown under desert conditions.

\section{MATERIALS AND METHODS}

Two field experiments were conducted at the extension field in El -Salhia region, Sharkia Governorate during 2004/2005 and 2005/2006 seasons to study the effect of different levels of nitrogen $(45,65$ and $85 \mathrm{~kg} \mathrm{~N} / \mathrm{fad})$ and glycinebetaine rates $(0,8$ and $12 \mathrm{mM} / \mathrm{fad})$ on the growth and yield of barley (Giza $124 \mathrm{cv}$.) under two water intervals (weekly irrigated and di-weekly irrigated). The soil texture of experimental field was sandy with $\mathrm{pH}$ of 8.1. The available $\mathrm{N}, \mathrm{P}$ and $\mathrm{K}$ contents were 18.2, 4.2 and $79 \mathrm{ppm}$, respectively.

A split-spilt plot design with 3 replicates was followed. Water intervals which began from 20 DAS using surface irrigation system were allotted to the main plots. The sub-plots were occupied by three levels of nitrogen, whereas, glycinebetaine rates were devoted to sub-sub plots. The sub plot area was $10.5 \mathrm{~m}^{2}(3 \times 3.5)$ including 15 rows, $20 \mathrm{~cm}$ apart. The preceding crop was peanut in both seasons.

Barley grains (Hordeum vulgare L.) were sown on $16^{\text {th }}$ and $19^{\text {th }}$ of November in the first and second seasons, respectively at a seeding rate of $50 \mathrm{~kg} / \mathrm{fad}$. Nitrogen levels as ammonium sulphate $(20.6 \% \mathrm{~N})$ were applied at three equal doses after 20,48 and 62 days from sowing. Glycinebetaine $(\mathrm{GB})$ rates $(0 \mathrm{~GB}$ : spray with tap water, 8 $\mathrm{mM}$ equal to $0.84 \mathrm{~kg} / \mathrm{fad}$ and $12 \mathrm{mM}$ equal to $1.26 \mathrm{~kg} / \mathrm{fad}$ were foliar applied in 80 liter water/fad after 35, 55, and 75 days from sowing. The recommend cultural practices for barley were applied as practiced in this region. Ten plants were randomly taken at 85 days from sowing for estimating the vegetative growth characters as follows: 
1- Plant height $(\mathrm{cm})$ was determined from the soil surface to the top of the main spike excluding awns.

2- Flag leaf blade area $\left(\mathrm{cm}^{2}\right)$.

3- Total chlorophyll $(\mathrm{mg} / \mathrm{g})$ :

Chlorophyll a and b were determined according to Fadeel (1962). The optical density of the extract was measured spectrophotometrically at $662 \mathrm{~nm}$ and $644 \mathrm{~nm}$ to determine chlorophyll a and $b$, respectively.

4- Relative water content (RWC) :

The relative water content was determined according to Schonfeld et al., (1988), where the fresh weight of twenty discs, from the youngest fully expanded leaf, were determined within 2 hours after excision. Turgid weight was obtained after soaking the discs for 16 to 18 hours in distilled water. After soaking, discs were immediately and carefully blotted dried with tissue paper prior to the determination of turgid weight. Dry weight was obtained after drying the discs sample for 72 hours at $70 \mathrm{C}^{\circ}$. Relative water content was calculated using the following equation:

$$
\mathrm{RWC}=\frac{\text { Fresh weight }- \text { dry weight }}{\text { Turgid weight }- \text { dry weight }} \quad \times 100
$$

At harvest, an area of $2 \mathrm{~m}^{2}$ from each plot was harvested to determine:

5- Number of spikes/ $\mathrm{m}^{2}$.

6- 1000 -grain weight (g).

7- Grain yield (ardab/fad).

8- Straw yield (ton/fad).

9- Mean productivity (ardab/fad):

Mean productivity is considered as the average yield in stress and non stress environment together. (Rosielle and Hamblin (1981).

In both seasons, the analysis of variance and least significant differences (LSD) were used separately to evaluate the response of each character within treatments according to Steel et al. (1997).

\section{RESULTS AND DISCUSSION}

1- Plant growth characters

Prolonging irrigation interval from 7 to 14 days decreased significantly the values of all growth characters for barley. The relative reduction percentages due to water stress were 14.58 and $11.74 \%, 25.41$ and $22.93 \%, 22.63$ and $19.98 \%$, and 25.11 and $26.19 \%$ for plant height, flag leaf blade area, total chlorophyll and relative water content in both seasons. It seems evident that subjecting barley plants to water stress, through prolonging irrigation interval reduced growth characters; probably due to impairing photosynthetic process and hence translocation of photosynthates from source to sink under water stress conditions. These results are in agreement with those obtained by Talukder (1987) and Abd Alla Kotb (2005).

It is evident from Table 1 that increasing N-level from 45 up to $85 \mathrm{~kg} \mathrm{~N} / \mathrm{fad}$ produced gradual and significant increases in all growth characters. Moreover, these 
results showed that addition of $85 \mathrm{~kg} \mathrm{~N} / \mathrm{fad}$ increased plant height, flag leaf blade area, total chlorophyll and relative water content by 14.52 and $12.07 \%, 12.80$ and $13.63 \%, 1.88$ and $3.50 \%$, and 3.28 and $4.59 \%$ in the first and second seasons compared with the addition of $45 \mathrm{~kg} \mathrm{~N} / \mathrm{fad}$, respectively. Paramjit et al. (2001) reported that $\mathrm{N}$-application led to increase the consumptive use of water, the water use efficiency of barley and soil moisture extraction. This might have played a role in improving plant drought tolerance, and consequently improved growth parameters of barley. These findings are in harmony with El Bawab et al. (2003) and El-Moselhy and Zahran (2003).

The effect of foliar application of GB on parley plant growth was significant in the both seasons (Table 1). The results indicated that the maximum values for growth characters were obtained from application of $12 \mathrm{mM}$ GB in both seasons. With increasing amount of GB up to $12 \mathrm{mM} /$ fad, plant height recorded in the both seasons and relative water content in the second season did not respond to more than $8 \mathrm{mM}$ $\mathrm{GB} / \mathrm{fad}$. Moreover, the results showed that the relative increase percentages due to application of $12 \mathrm{mM}$ GB were 21.49 and $30.35 \%$ for plant height, 20.63 and $23.06 \%$ for flag leaf blade area, 32.30 and $35.80 \%$ for total chlorophyll and 22.57 and $30.40 \%$ for relative water content in the first and second seasons, respectively compared with untreated plants. These results are in harmony with those obtained by Agboma et al. (1997), Naryyar and Walia (2004) and Abd Alla Kotb (2005).

Figures 1 to 6 explain the significant interactions effects among the three factors under study. The interaction between irrigation treatments and $\mathrm{N}$ fertilizer levels showed a significant effect on plant height, flag leaf blade area in both seasons and total chlorophyll in second season (Figures 1 and 2). The highest values of these traits were obtained from weekly irrigation with $85 \mathrm{~kg}$ N/fad. Meanwhile, the lowest values were obtained from di-weekly irrigation with $45 \mathrm{~kg} \mathrm{~N} / \mathrm{fad}$. Under water stress, increasing N-levels from 45 to 65 or to $85 \mathrm{~kg} \mathrm{~N} /$ fad increased significantly the values of these traits except the total chlorophyll which did not respond to $\mathrm{N}$ application under stress condition.

Concerning to the interaction between irrigation treatments and GB, results in Figures 3 and 4 showed that both of them interacted with each other significantly for all growth characters. Plant height, flag leaf blade area, total chlorophyll and relative water content were gradually increased by decreasing irrigation interval and increasing GB concentration up to $12 \mathrm{mM} / \mathrm{fad}$. Under drought condition and spray with $12 \mathrm{mM} \mathrm{GB} / \mathrm{fad}$, the response of plant height, flag leaf blade area, total chlorophyll and relative water content was 80.95 and $75.27 \mathrm{~cm}, 10.44$ and $10.45 \mathrm{~cm}^{2}$, 17.78 and $15.35 \mathrm{mg} / \mathrm{g}$, and 60.72 and $56.23 \%$ compared with 59.85 and $54.66 \mathrm{~cm}$, 8.24 and $8.00 \mathrm{~cm}^{2}, 12.78$ and $10.94 \mathrm{mg} / \mathrm{g}$, and 46.53 and $39.59 \%$ when the concentration of GB was decreased to zero in both seasons, respectively. Stressed plants received GB accumulated more chlorophyll and had higher relative water content than their untreated analogues. These results indicate, also, that barley plants responded to GB addition in both seasons under frequent irrigation as well as drought condition. 

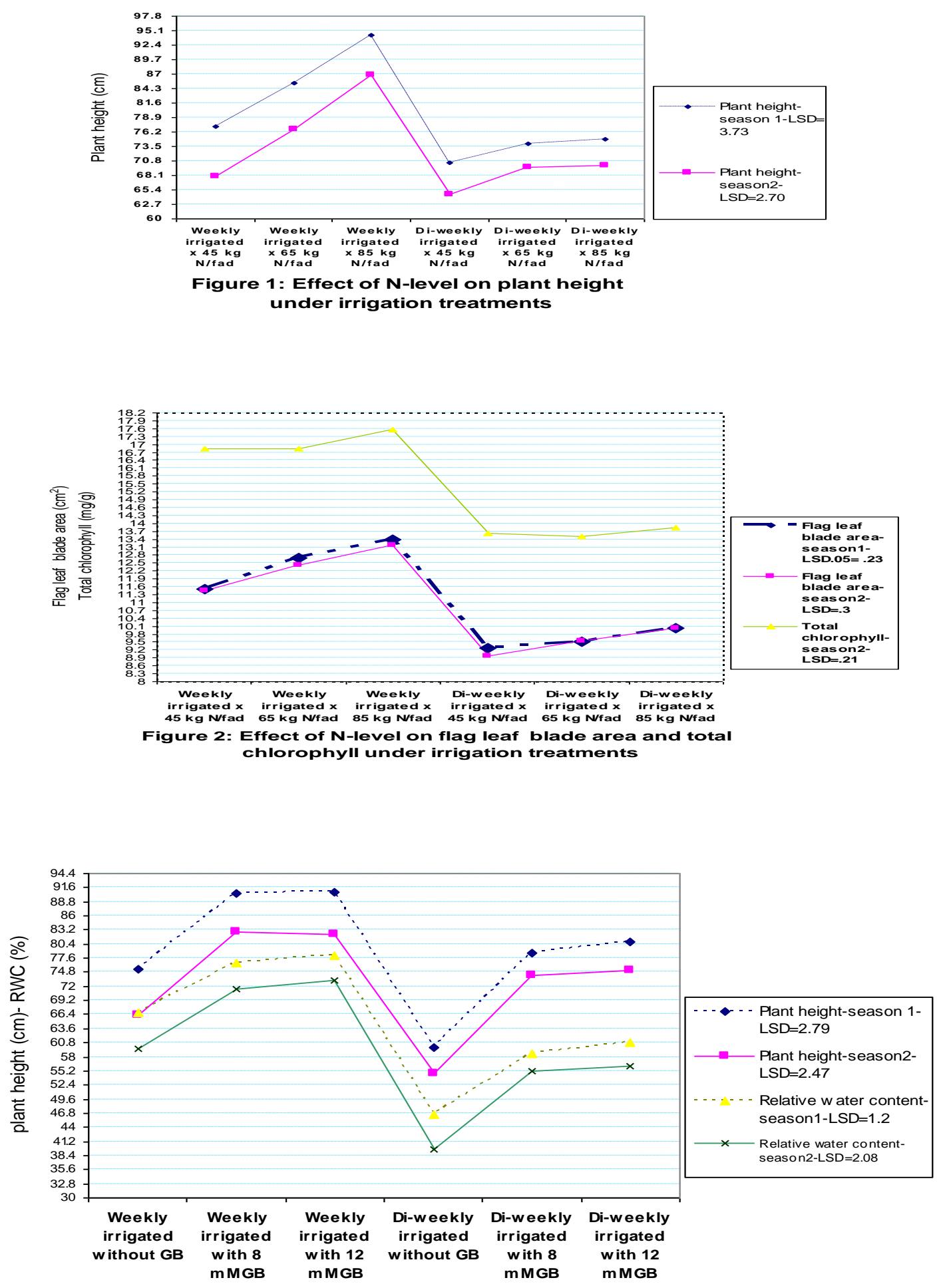

Figure 3: Effect of foliar application of GB on plant height and RWC under irrigation treatments 

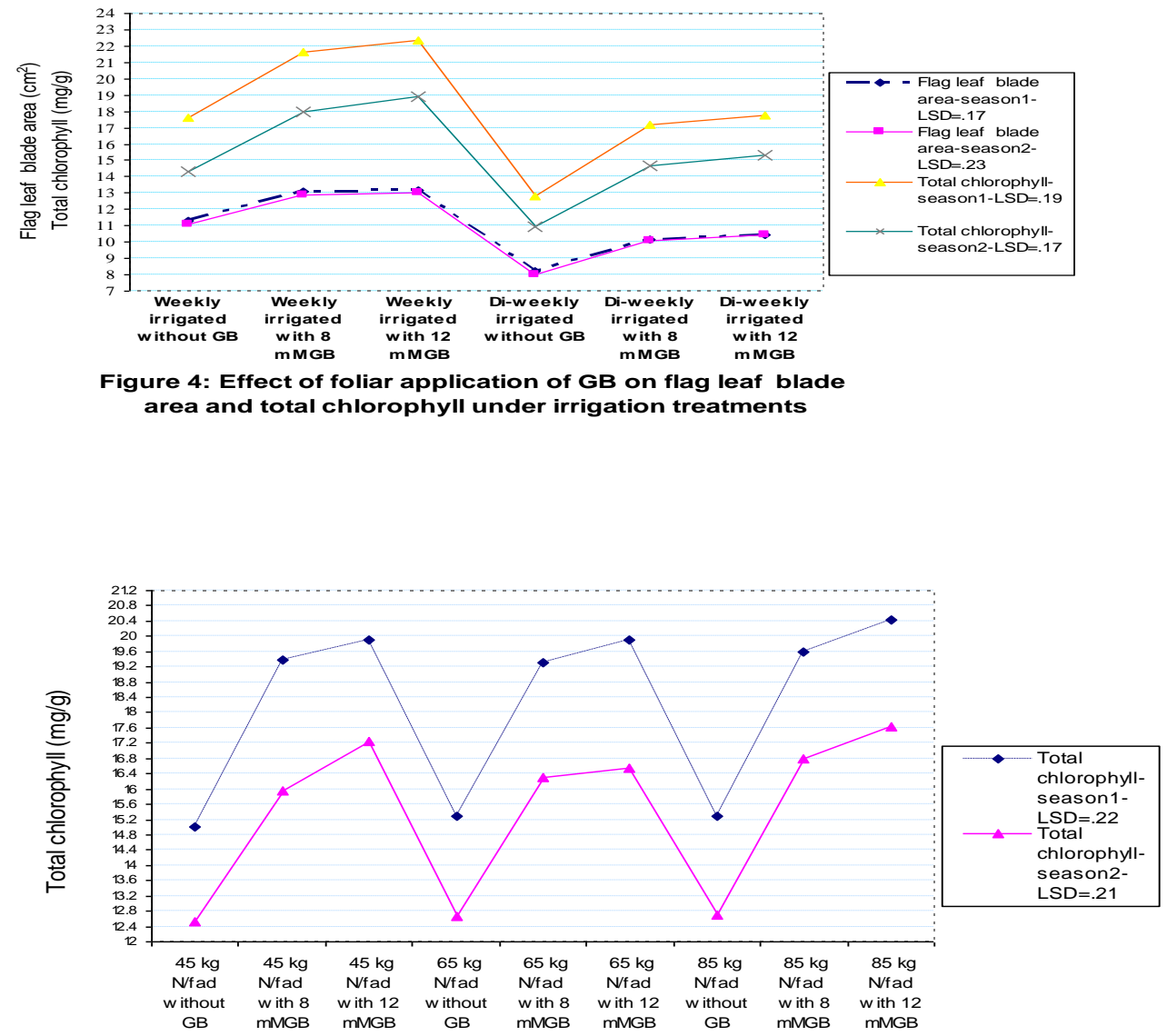

Figure 5: Interaction effect between $\mathbf{N}$ and $\mathrm{GB}$ levels on total chlorophyll

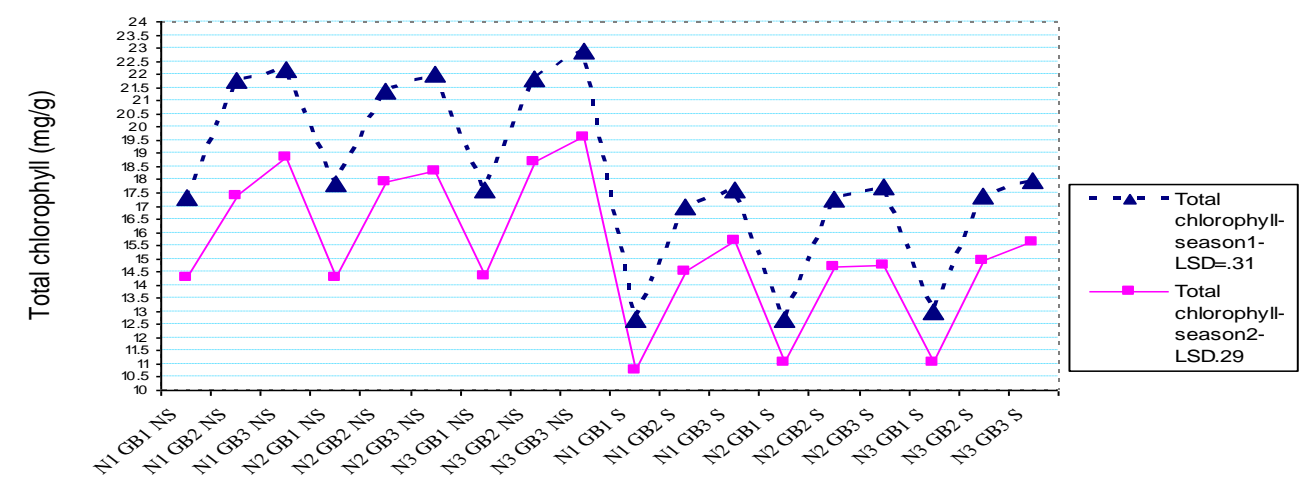

Figure 6: Interaction effect between $\mathrm{N}$ and $\mathrm{GB}$ levels on total chlorophyll under irrigation treatments.

(N1, N2 and N3: 45, 65 and $85 \mathrm{kgN} / \mathrm{fad}$. GB1, GB2 and GB3: 0, 8 and 12 $\mathrm{mM} \mathrm{GB/fad.} \mathrm{NS}$ and S: Weekly and Di-weekly irrigated, respectively) 
Generally, Figure 5 shows that increasing N level from 45 to $85 \mathrm{~kg}$ N/fad with zero GB, total chlorophyll did not respond to $\mathrm{N}$-levels in both seasons. Meanwhile, increasing GB concentration up to $12 \mathrm{mM}$ / fad significantly ameliorate the values of this trait.

The same observation was obtained from the interaction among the three factors in both seasons (Figure 6). Under stress condition or non stress condition, increasing $\mathrm{N}$ level from 45 to $85 \mathrm{~kg}$ /fad with zero GB, the total chlorophyll did not respond to $\mathrm{N}$ levels. Meanwhile, this trait was increased significantly with increasing GB from zero to $12 \mathrm{mM}$.

It could be concluded that stressed plants received GB accumulated more chlorophyll and had higher relative water content than their untreated analogues. This could be due to increasing the stability of chloroplast membranes (Mamedove et al. 1991), protection of photosystem 2 by GB (Papageorgiou et al. 1991), improved water status and reduced transpiration via effects on stomatal regulation. These beneficial effects of GB might have improved the growth of barley under adverse conditions. These results are in harmony with those obtained by Abd Alla Kotb (2005).

\section{2- Barley yield and its attributes}

Prolonging the period of irrigation from 7 to 14 day reduced significantly the yield and its attributes in both seasons (Table 2). The relative reduction percentages were 23.68 and $22.03 \%, 14.82$ and $14.48 \%, 22.73$ and $26.02 \%$, and 26.73 and $24.79 \%$ for number of spikes, 1000-grain weight, grain and straw yields/fad in both seasons, respectively. In the same trend, the results obtained by Talukder (1987) and Ni et al. (1992) refer that drought during the vegetative growth stage indirectly affected on yield potential by adversely affecting leaf area and photosynthetic capacity. These results are in agreement with Tanoj-Chaudhary and Sharma (2003) and Abd Alla Kotb (2005).

Table 2 showed also that number of spikes, 1000-grain weight, grain yield, straw yield and mean productivity were significantly increased by increasing $\mathrm{N}$-level from 45 to $85 \mathrm{~kg} \mathrm{~N} /$ fad and GB concentration from zero to $12 \mathrm{mM} \mathrm{GB} / \mathrm{fad}$ in both seasons. The relative increase percentages due to addition of $85 \mathrm{~kg} \mathrm{~N} / \mathrm{fad}$ in comparison with $45 \mathrm{~kg} \mathrm{~N} / \mathrm{fad}$ were 9.26 and $12.28 \%, 4.89$ and $7.68 \%, 12.84$ and $12.78 \%, 16.43$ and $14.7 \%$, and 12.88 and $12.85 \%$ in both seasons, respectively. These results are in harmony with those obtained by Basha and El-Bana (1994) and Abd Alla, Maha (2004). Meanwhile, the relative increase percentages due to application of $12 \mathrm{mM} \mathrm{GB} /$ fad compared with zero GB were 22.18 and $25.50 \%, 12.49$ and $15.35 \%$, 21.27 and $24.77 \%, 24.82$ and $26.83 \%$, and 21.30 and $24.73 \%$ for these traits, respectively. These results mean that $\mathrm{N}$ had little effect compared with foliar application of GB on growth and yield of barley. In the same trend, Abd Alla Kotb (2005) reported that growth and yield of wheat were increased due to the application of 8 or $12 \mathrm{mM} \mathrm{GB} / \mathrm{fad}$.

Concerning to the interaction between water stress treatments and N-levels, the results showed significant effects on number of spikes $/ \mathrm{m}^{2}$, grain yield and straw yield (Figures 7, 8 and 9). Weekly irrigation with the addition of $85 \mathrm{~kg} \mathrm{~N} / \mathrm{fad}$ gave the 


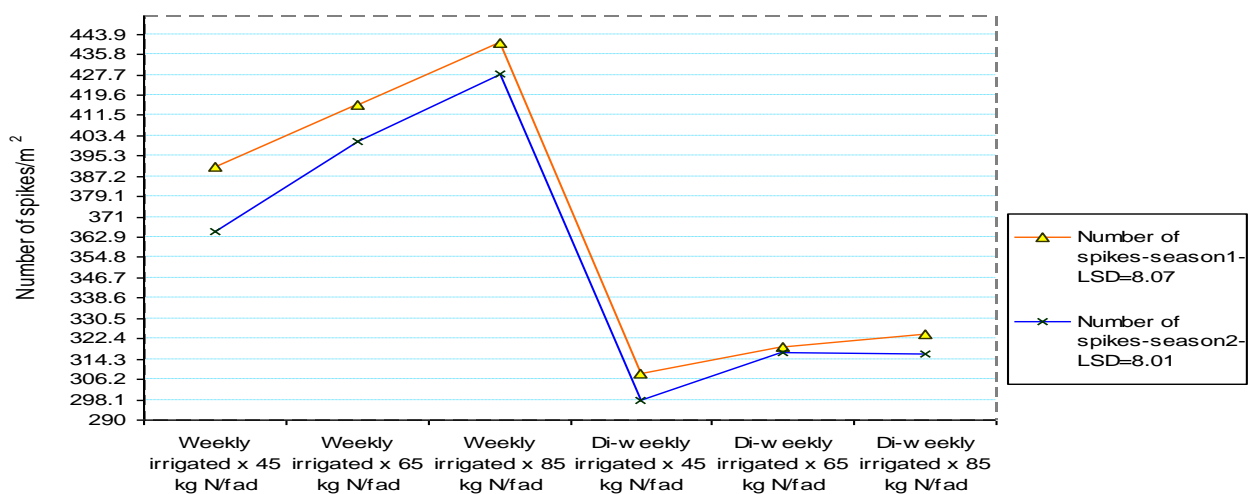

Figure 7: Effect of $\mathrm{N}$-level on number of spikes under irrigation treatments

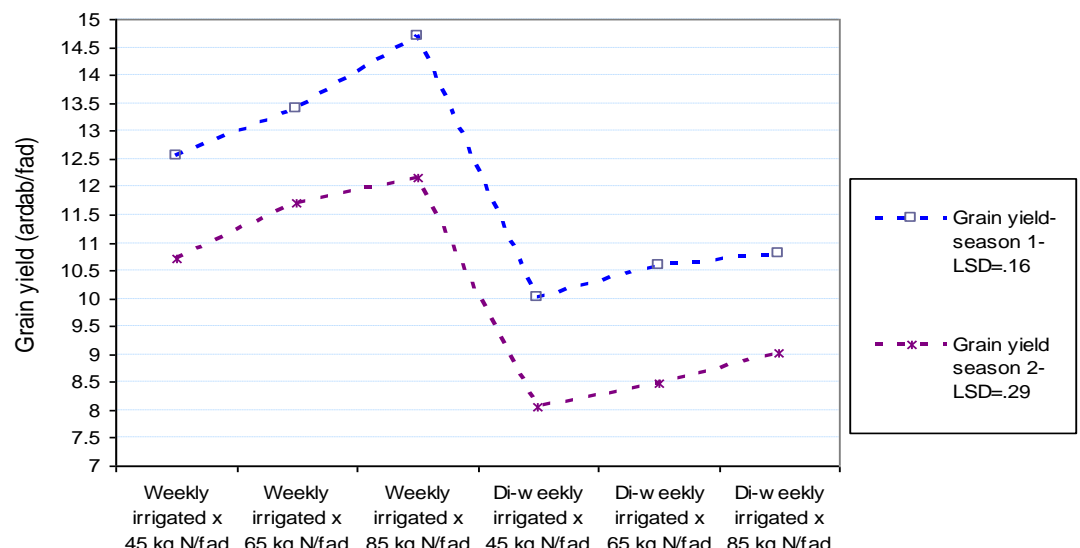

Figure 8: Effect of $\mathrm{N}$-level on grain yield under irrigation treatments

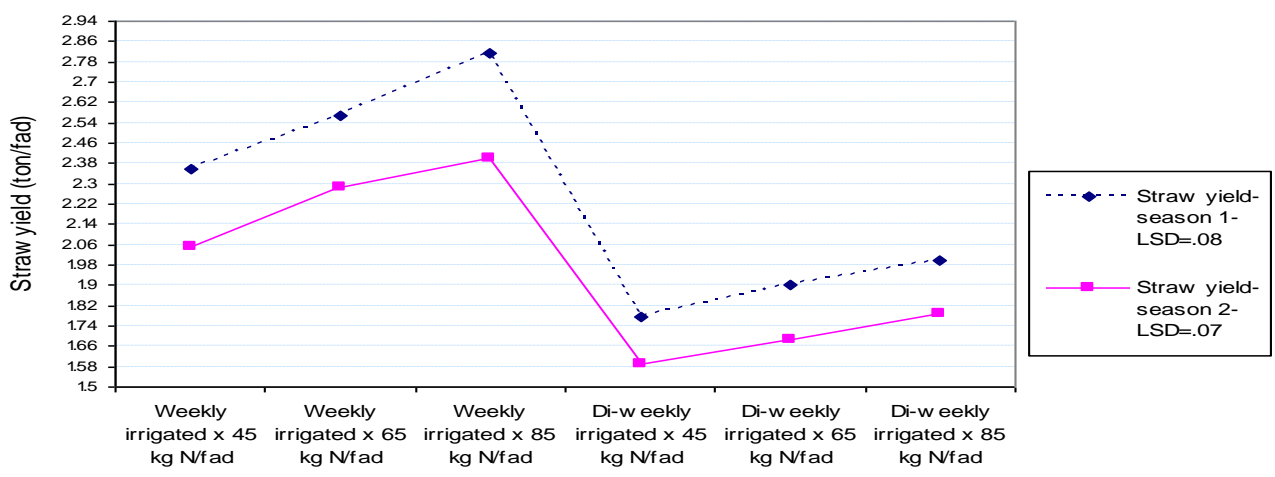

Figure 9: Effect of $\mathrm{N}$-level on straw yield under irrigation treatments 
maximum averages of these traits. Under water stress, raising $\mathrm{N}$ level improved significantly these traits in both seasons. Sing and Kumar (1981) indicated that nitrogen fertilizer with marginal additional water use increased barley yield linearly by $45.15 \%$. These results are in agreement with those obtained by Basha and El-Bana (1994) and Abd Alla, Maha (2004).

Figures 10 and 11 illustrate that under frequent irrigation or drought condition, increasing GB-levels from zero to $12 \mathrm{mM} /$ fad produced gradual and significant increase in number of spikes, 1000-grain weight and grain yield in both seasons. Generally, the interaction between weekly irrigation and 8 or $12 \mathrm{mM} \mathrm{GB} /$ fad gave the highest values of these traits. Moreover, Figure (11) indicate that under drought condition and without GB addition, the response of grain yield was only 8.95 and 7.07 ardab/fad in comparison with 11.11 and $9.10 \mathrm{ardab} / \mathrm{fad}$ when the concentration of GB was increased to $8 \mathrm{mM} /$ fad in both seasons, respectively.

Increasing both of N-level and GB concentration resulted in increasing of grain yield in the first season (Figure 12).

Figure 13 explain that under drought condition or frequent irrigation, increasing level of $\mathrm{N}$ and GB produced gradual and significant increases in 1000-grain weight in the second season and grain yield in the first season, respectively. Moreover, 11.38 ardab/fad was obtained from frequent irrigation, zero GB and $45 \mathrm{~kg} \mathrm{~N} / \mathrm{fad}$ in comparison with 15.34 ardab / fad which was obtained from frequent irrigation, $8 \mathrm{mM}$ $\mathrm{GB} / \mathrm{fad}$ and $85 \mathrm{~kg} \mathrm{~N} / \mathrm{fad}$. Meanwhile, the drought, zero GB and $45 \mathrm{~kg} \mathrm{~N} /$ fad treatment gave 8.66 ardab / fad compared with 11.69 ardab / fad which was obtained from drought, $8 \mathrm{mM} \mathrm{GB} / \mathrm{fad}$ and $85 \mathrm{~kg} \mathrm{~N} / \mathrm{fad}$ treatment. It is clear that exogenous glycinebetaine might have had increased photosynthetic activity, nitrogen fixation, leaf area and grain yield as reported in maize, sorghum and wheat by Agboma et al., (1997), Naryyar and Walia (2004) and Abd Alla Kotb (2005), in respective order.

From these results, it could be concluded that nitrogen had a higher positive effect on grain yield and its attributes under drought condition by irrigation every 14 days than under frequent condition. This may be due to nitrogen acted to ameliorate the consumptive use of water, the water use efficiency of barley, and soil moisture extraction (Paramjit et al., 2001). In addition, foliar application of GB had also major effect on these traits under stress condition. This effect may be due to a possible decrease in the sensitivity of RWC in barley leaves and hence the photosynthetic pigments to photoinhibition caused by drought stress. These results indicate that GB acted as osmoregulation substance and enhanced the response of barley plants to water stress when was applied by a proper amount. 


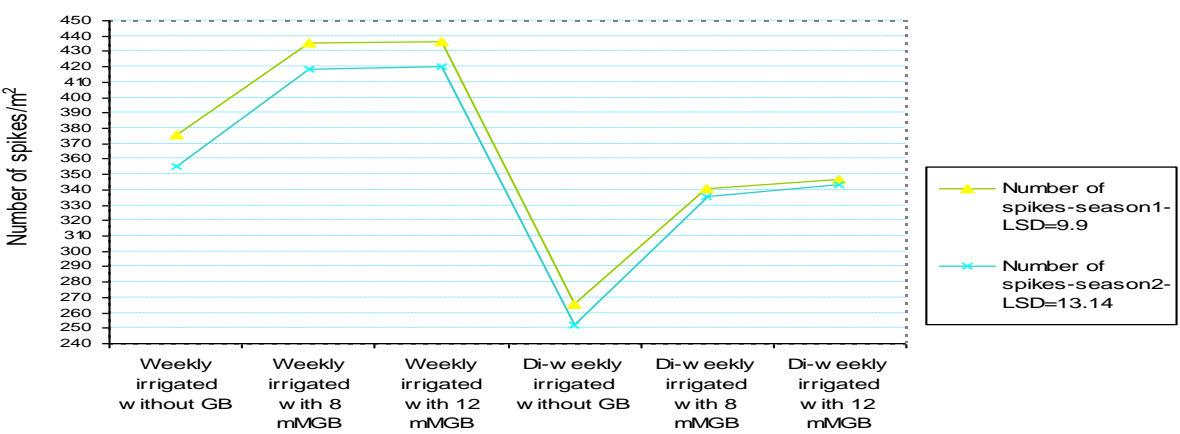

Figure 10: Effect of foliar application of $G B$ on number of spikes under irrigation treatments
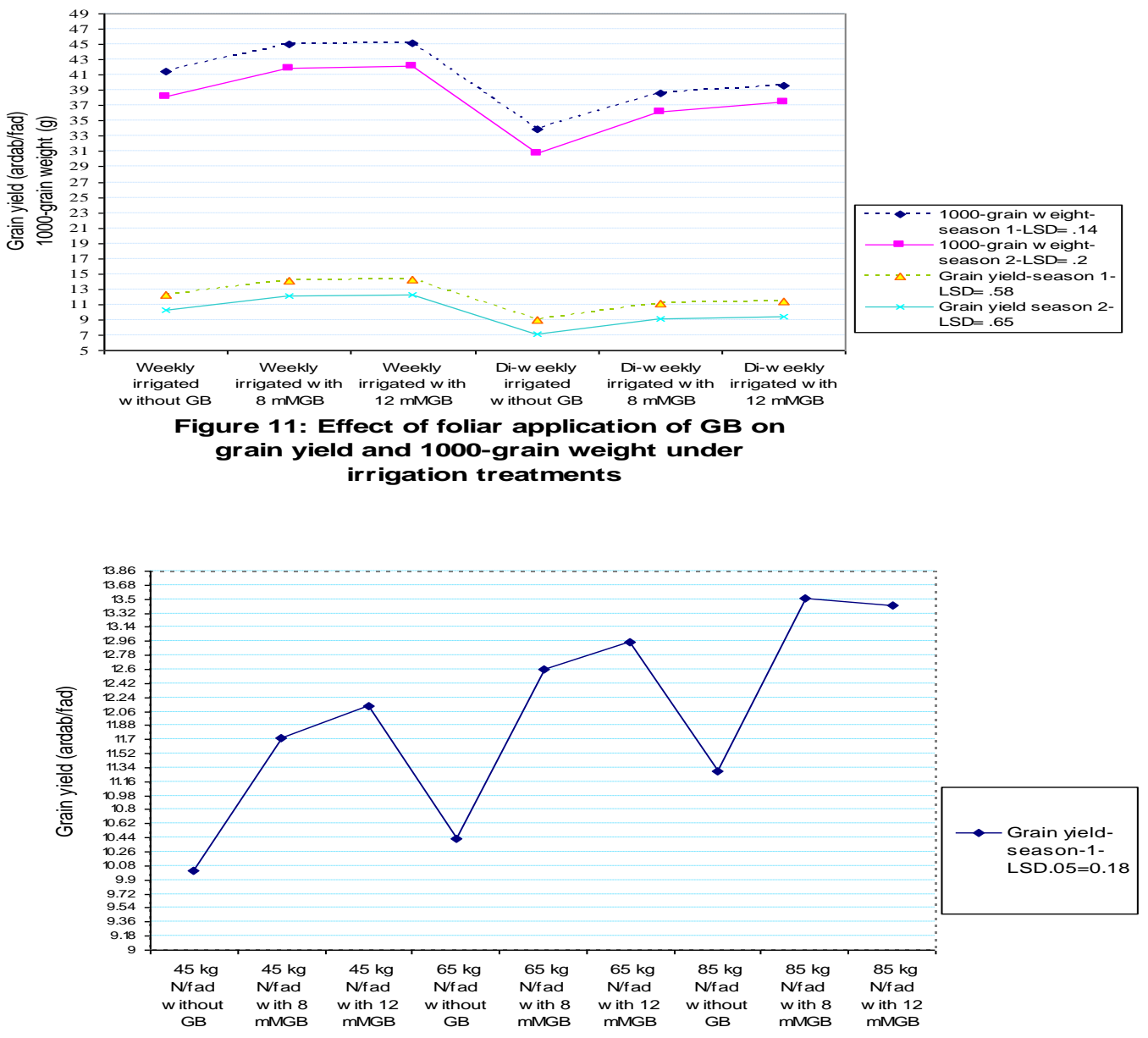

Figure 12: Interaction effect between $N$ and $G B$ levels on grain yield 


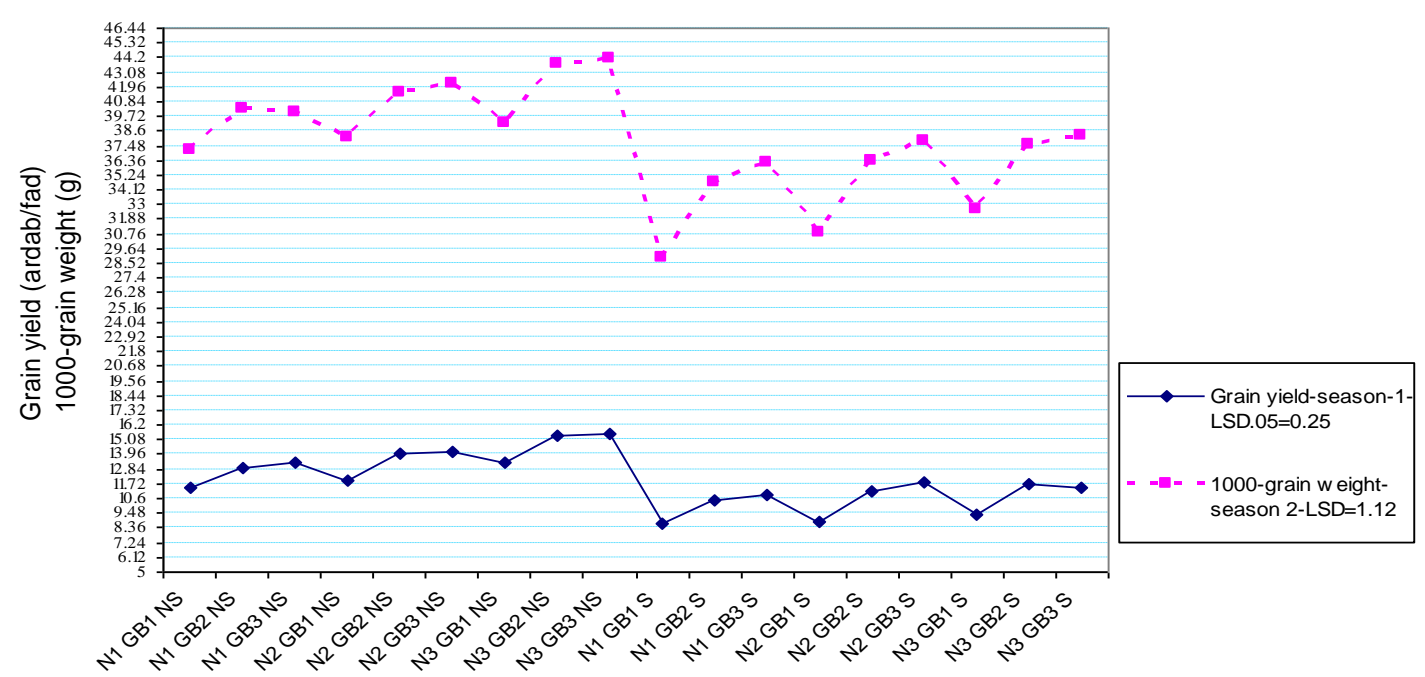

Figure 13: Effect of $\mathrm{N}$-level and foliar application of GB on grain yield and 1000-grain weight under irrigation treatments

(N1, N2, N3: 45, 65, 85 kg N/fad. - GB1, GB2, GB3: 0, 8, 12 mM GB/fad. - NS and S: Weekly and Di-weekly irrigated, respectively)

\section{REFRENCES}

Abd Alla Kotb, M. (2005) Effect of foliar application of glycinebetaine on growth and yield of wheat (Triticum aestivum L.) under water stress. The $11^{\text {th }}$ Conference of Agronomy, Agro. Dept., Fac. Agric., Assiut Univ., Nov. 15-16., 65-79.

Abd Alla, Maha M. (2004) Influence of nitrogen level and its application time on yield and quality of some new hull-less barley. J. Agric. Sci. Mansoura Univ., 29 (5): 2201-2216.

Agboma P. C.; Jones; M. G. K.; Peltonen-Sainio, P.; Rita, H. and Pehu, E. (1997) Exogenous glycinebetaine enhances grain yield of maize, sorghum and wheat grown under two supplementary watering regimes. J. Agron. and Crop Sci., 178: 29-37.

Allard, F.; M .Houde; M. Krol; A. Ivanovand F. Sarhan (1998) Betaine improves freezing tolerance in wheat. Plant Cell Physiol, 39: 1194-2202.

Basha, H. A. and El-Bana, A. Y. A. (1994) Effect of nitrogen fertilization on barley in newly cultivated sandy soil. Zagazig J. Agric. Res., 21(4): 1053-1066.

Ehaid, B.; Waines, J. G. and Hall, A.F. (1988) Differential responses of Landrace and Improved spring wheat genotypes to stress environments. Crop Sci., 28: 838-842.

El Bawab, A. M. O.; El-Moselhy, M. A and Megahed, M. A. (2003) Water and nitrogen fertilizer requirements for barley in sandy soils. Egypt. J. Appli. Sci., 18 (17): 125-133. 
El-Moselhy, M. A and Zahran, F. A. (2003) Effect of bio and mineral nitrogen fertilization on barley crop grown on a sandy soil. Egyptian J. of Agric. Res., 81(3): 921-935.

Fadeel, A. A. (1962) Location and properties of chloroplast and pigment determination in roots. Physiol. Plant, 15: 130-147.

Grote, E. M., G. Ejeta and D. Rhodes (1994) Inheritance of glycinebetaine deficiency in sorghum. Crop Sci., 34:1217-1220.

Jagendrof, A. T. and Takab, T. (2001) Inducers of GB synthesis in barley. Plant Physiol., 127: 1827-1835.

Makela, P.; Peltonen-Sainio P.; Jokinen K.; Pehu E.; Setala H.; Hinkkanen R. and Somersalo S.(1996) Uptake and translocation of foliar-applied glycinebetaine in crop plants. Plant Sci., 121: 221-230.

Mamedov, M.; Hayashi H.; Wada H.; Mohanty PS.; Papageoriou, GC. and Murata, N. (1991) Glycinebetaine enhances and stabilizes the evolution of oxygen and the synthesis of ATP by cyanobacterial thylakoid membranes. FFBS Lett., 294: 271-274.

Martin, M.; Morgan, J. A.; Zerbi, G. and Lecaain, D. R. (1997) Water stress imposition rate affects osmotic adjustment and cell wall properties in winter wheat. Italian, J. Agron., 1: 11-20.

Nayyar, H. and Walia, D. P. (2004) Genotypic variation in wheat in response to water stress and abscisic acid-induced accumulation of osmolytes in developing grains. J. Agron. and Crop Sci., 190: 39-45.

Ni, B. R. (1992) Stomatal and stomatal limitations to net photosynthesis in seeding of woody angiosperms. Plant. Physiol., 99: 1502-1508.

Papageoriou, GC., Fujimura, Y. and Murata, N. (1991) Protection of the oxygenevolving Photosystem 11 complex by glycinebetaine. Biochim. Biophys. Acta, 1057: 361-366.

Paramjit-; Singh,-V-P and Roy,-D-K (2001) Effect of different levels of nitrogen and irrigation on water use efficiency and moisture extraction pattern of malt barley var. Alfa-93. Crop Res. Hisar, 22(2): 155-157.

Rhodes, D. and A. D Hanson (1993) Quaternary ammonium and tertiary sulfonium compounds in higher plants. Annu. Rev. Plant Physiol., Plant Mol. Biol., 44: 357-384.

Rosielle, A. A., and J. Hamblin (1981) Theoretical aspects of selection for yield in stress and non stress environments. Crop Sci., 21:943-945.

Schonfeld, M. A.; R. C. Johnson; B. F. Carver, and D. W. Mornhinweg (1988) Water relations in winter wheat as drought resistance indicators. Crop Sci., 28: 536-541.

Sing, K. P. and Kumar V. (1981) Water use efficiency of wheat and barley in relation to seeding dates, levels of irrigation and nitrogen fertilization. Agric. Water Management, 3 (4): 305-316.

Steel, G. D.; J. H. Torrie and D. A. Diskey (1997) Principles and procedures of statistics: A Biometrical approach $3^{\text {rd }}$ ed. Mc Graw-Hill, New York. 
Talukder, M. S. U. (1987) Growth and development of wheat as affected by soil moisture stress. Indian J. Agric. Sci., 57: 559-564.

Tanoj-Chaudhary and Sharma,-D-D (2003) Response of barley (Hordeum vulgare L.) to different varieties and irrigation levels. Current-Agric., 27(1/2): 139141.

\title{
تأثير مستويات مختلفة من النيتروجين والجلايسين بيتايين على نمو ومحصول الثعير تحت ظروف الجفاف
}

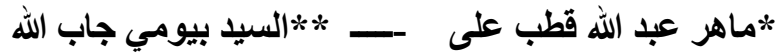

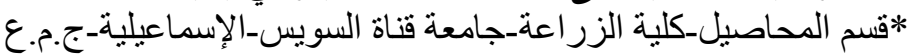

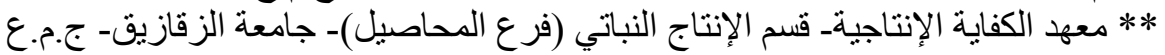

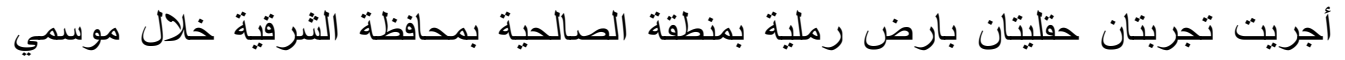

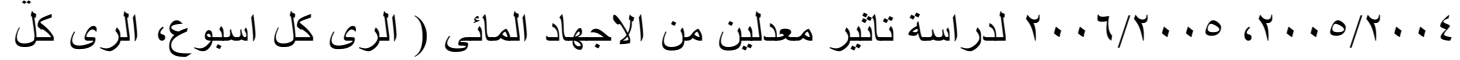

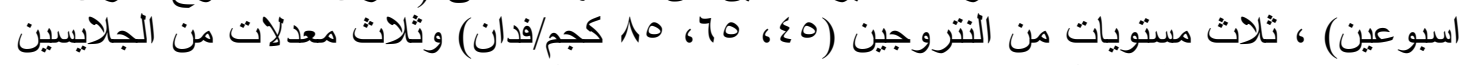

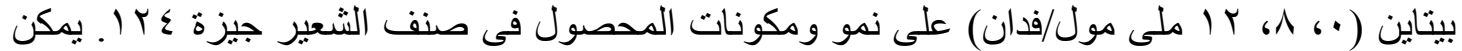

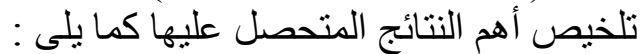

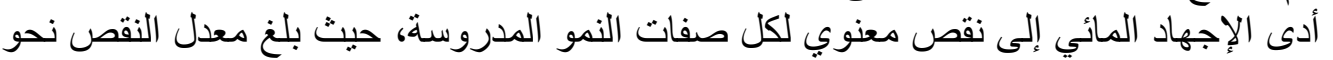

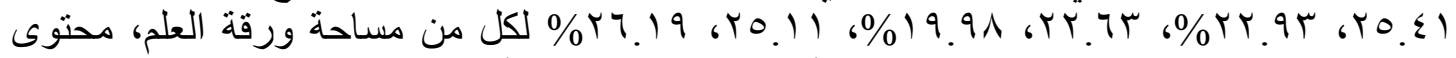

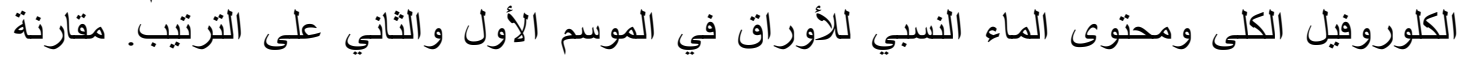

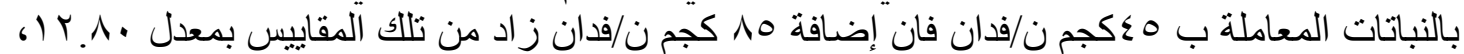

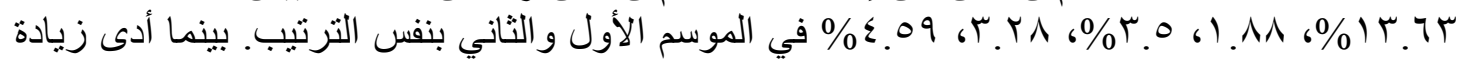

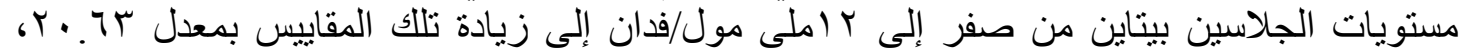

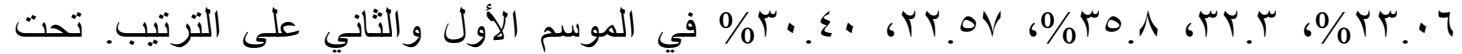

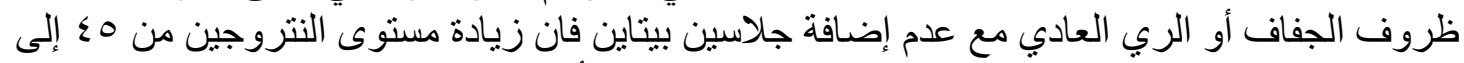

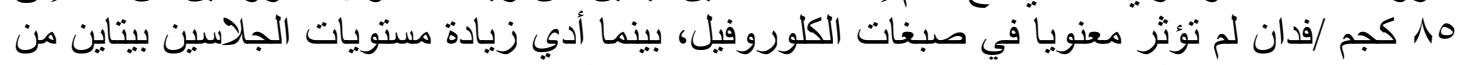

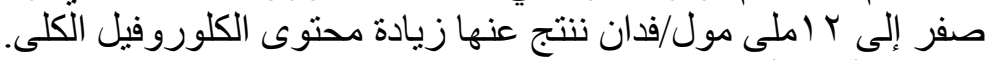

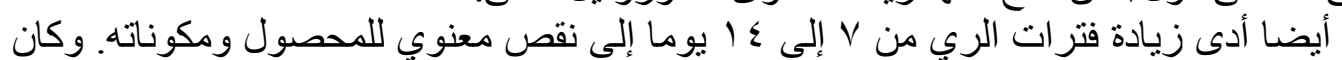

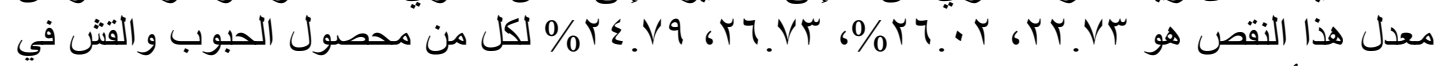

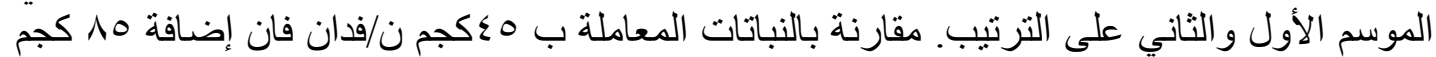

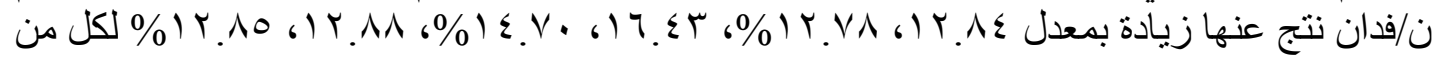

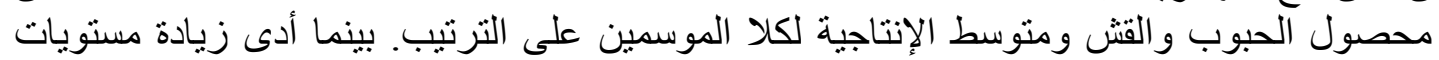

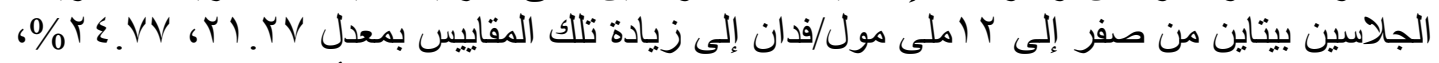

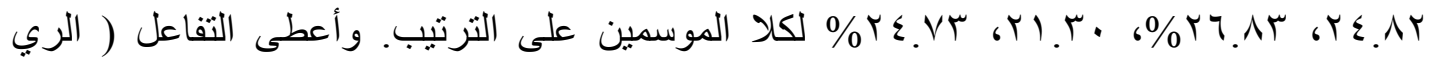

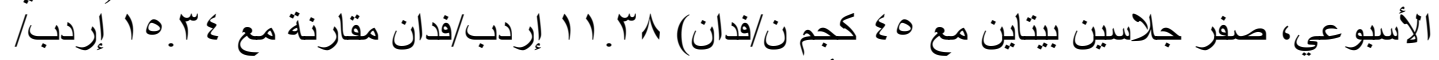

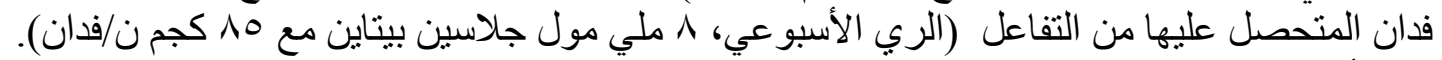

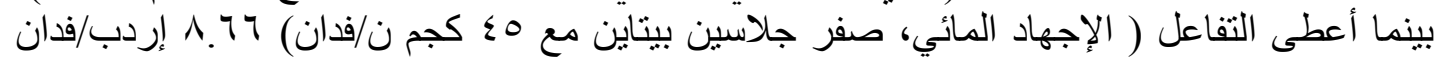

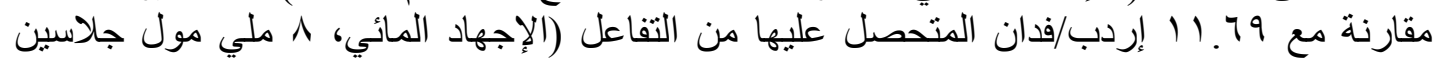
بيتاين مع 10 كجم ن/فدان) 